\title{
Persepsi Guru dan Siswa terhadap Penerapan Model Discovery secara Daring pada Pembelajaran Menulis Naskah Ceramah
}

\section{Teacher and Student Perceptions for Implementation of the Online Discovery Model in the Writing Speech Script Learning}

\author{
Abdul Rahman ${ }^{1, *}$, Yusak Hudiyono ${ }^{2}$, dan Bibit Suhatmady ${ }^{3}$ \\ ${ }^{1}$ Magister Pendidikan Bahasa dan Sastra Indonesia, FKIP, Universitas Mulawarman \\ ${ }^{2,3}$ FKIP Universitas Mulawarman \\ ${ }^{1}$ Corresponding email: rafasyah02al@gmail.com \\ ${ }^{2}$ E-mail: yusak.hudiyono@,fkip.unmul.ac.id \\ ${ }^{3}$ E-mail: bitsuteaching@yahoo.com.au
}

Received: 1 October 2021 Accepted: 18 October 2021 Published: 5 November 2021

\begin{abstract}
Implementation of online learning with the application of the invention model increases perceptions between teachers and students. This study aims to determine the perceptions of teachers and students about the implementation of the invention model online in writing script learning. The research method used is a qualitative method using a case study approach. The population in this study were Indonesian language subject teachers and ten-grade students. The sample was taken using the purposive sampling technique. Data collection techniques are carried out by filling out a questionnaire through the Google form and interviews with teachers and students.
\end{abstract}

Keywords: perception, discovery model, speech script writing

Abstrak: Implementasi pembelajaran online dengan penerapan model penemuan menaikkan persepsi antara guru dan siswa. Penelitian ini bertujuan untuk mengetahui persepsi guru dan siswa tentang implementasi model penemuan online dalam pembelajaran menulis naskah ceramah. Metode penelitian yang digunakan adalah metode kualitatif menggunakan pendekatan studi kasus. Populasi dalam penelitian ini adalah guru mata pelajaran bahasa Indonesia dan siswa kelas sepuluh. Sampel diambil dengan menggunakan teknik purposive sampling. Teknik pengumpulan data dilakukan dengan mengisi kuesioner melalui Google Form dan juga wawancara dengan guru dan siswa.

Kata kunci: persepsi, model discovery, menulis naskah ceramah

To cite this article:

Rahman, A., Hudiyono, Y., \& Suhatmady, B. (2021). Persepsi Guru dan Siswa terhadap Penerapan Model Discovery secara Daring pada Pembelajaran Menulis Naskah Ceramah. Diglosia: Jurnal Kajian Bahasa, Sastra, dan Pengajarannya, 4(4), 453-460. https://doi.org/10.30872/diglosia.v4i4.307

\section{A. PENDAHULUAN}

Pendidikan saat ini telah banyak mengalami perkembangan. Perkembangan teknologi telah membawa perubahan yang sangat besar bagi kemajuan dunia pendidikan. Seiring dengan perkembangan tersebut metode pembelajaran juga banyak mengalami perkembangan baik dari segi metode dan model dalam pembelajaran. Dalam penelitian Daniel et al. (2016) mencatat adanya peningkatan pembelajaran daring antara tahun 2009 dan 2010 sebesar 21\%. Pembelajaran daring 
juga merupakan inovasi dalam dunia pendidikan yang di dalamnya melibatkan teknologi informasi.

Pembelajaran secara daring di masa pandemi Covid-19 dengan penerapan model discovery menimbulkan persepsi antara guru dan siswa. Persepsi adalah suatu proses menginterpretasikan makna dalam memahai sebuah informasi (Simbolon, 2008). Persepsi juga merupakan cara untuk menarik lebih banyak informasi dan melakukan pemeriksaan lebih luas dalam berbagai disiplin ilmu. Dengan ini, persepsi dapat katakan sebagai bentuk pemahaman dalam memaknai suatu informasi yang lebih luas.

Pelaksanaan proses pembelajaran daring selama pandemi ini, terdapat persepsi antara guru dan siswa tentang penerapan model discovery. Model discovery adalah suatu model pembelajaran yang mengarahkan siswa dalam menemukan pembelajaran yang bermakna (Rosarina et al., 2012). Penerapan model discovery, pada dasarnya dapat memberikan kepercayaan kepada siswa untuk melatih dirinya dalam mengembangkan bakatnya. Model juga dapat diartikan sebagai startegi atau teknik untuk mencapai tujuan pembelajaran (Afandi et al., 2013).

Penerapan model pembelajaran menjadi poin utama dalam proses pembelajaran untuk dapat mengubah siswa lebih aktif. Untuk menjadikan siswa lebih aktif, guru perlu menetapkan suatu model pembelajaran. Menentukan model dan strategi belajar, dapat memberi pengalaman dan pengajaran kepada siswa (Abdallah \& Mansour, 2015). Dalam penemuan model pembelajaran juga dapat mengarahkan peserta didik untuk belajar secara maksimal.

Penerapan model discovery, pada dasarnya dapat memberikan kepercayaan kepada siswa untuk melatih dirinya dalam mengembangkan bakatnya. Adeninawaty (2018) berpendapat bahwa penerapan model discovery dapat menumbuhkan minat belajar juga memotivasi siswa dalam mengikuti pembelajaran. Tanggaard (2014) mengatakan bahwa penemuan model dalam pembelajaran merupakan kreativitas yang diperlukan dalam pembelajaran. Pembelajaran dalam penemuan memberikan kesempatan kepada siswa untuk belajara menemukan sendiri dan fokus pada tugas yang diberikan (Skeen \& Zafonte, 2015).

Sementara pendapat (Magnani, Nersessian, \& Thagard, 1999) mengatakan sesuatu hal yang menghasilkan perubahan, menciptakan pemikiran baru adalah suatu bentuk penalaran berbasis model. Belajar dengan adanya penerapan model dapat memberi kepercayaan kepada siswa untuk belajar mandiri Turan \& Matteson (2021). Pembelajaran secara daring pada materi menulis naskah ceramah sangat perlu memperhatikan model pembelajaran. Adanya penemuan model pembelajaran dalam menulis naskah ceramah diyakini dapat menjadikan siswa kreatif dalam membangun pengetahuannya sendiri (Balim, 2009). Pada dasarnya pembelajaran menulis naskah ceramah yang dilakukan secara daring memerlukan keterlibatan siswa. Keterlibatan siswa dalam pembelajaran secara daring mampu menciptakan pengetahuan yang membawa kesuksesan (Martin \& Bolliger, 2018).

Menulis adalah suatu kemampuan dalam mentransfer bahasa dalam bentuk tulisan (Saputro et al., 2021). Menulis merupakan suatu kerampilan berbahasa yang merupakan suatu wadah dari keterampilan berbahasa lisan (Rastle, 2019). Dasar utama yang diperlukan dalam pelajaran menulis naskah ceramah secara daring adalah keaktifan dan kreativitas siswa. Sabaruddin (2019) menyatakan bahwa menulis merupakan keterampilan dalam menyusun kata-kata yang dapat 
dikomunikasikan. Pembelajaran menulis naskah ceramah secara daring dapat terlaksana dengan baik tergantung dari fasilitas dan juga guru (Sherbino et al., 2013).

Menulis dipandang salah satu dari kemampuan berbahasa. Kemampuan sesorang dalam menulis tidak muncul begitu saja. Membaca dengan baik akan menghasilkan keterampilan dalam menulis yang baik pula (Traweek, 2017). Menulis merupakan satu kesatuan dalam ketempilan berbicara. Kemampuan sesorang dalam menghasilkan tulisan yang baik tergantung dari cara berpikirnya (Kellogg \& Raulerson, 2007). Keterampilan dalam menulis juga mempengaruhi kemampuan dalam berbahsa. Siswa yang terampil dalam menulis memiliki wawasan dan pengetahuan yang lebih luas.

Tujuan dari penelitan ini adalah untuk mengetahui persepsi guru dan siswa tentang implementasi model penemuan online dalam pembelajaran menulis naskah ceramah. Selain itu, penelitian ini bertujuan mengetahui keefektifan model discovery yang dilaksanakan secara daring pada pembelajaran menulis naskah ceramah.

\section{B. METODE}

Metode penelitian yang digunakan adalah metode kualitatif dengan menggunakan pendekatan studi kasus. Teknik analisis data yang digunakan adalah teknik analisi deskriptif kualitatif, reduksi data, verifikasi data, dan triangulasi data. Partisipan dalam penelitian ini adalah guru mata pelajaran bahasa Indonesia sebanyak 4 orang dan 66 siswa dari kelas XI. Sampel yang digunakan dengan menggunakan teknik purposive sampling. Pengukuran skor data dari hasil angket dihitung dengan pengukuran skala likert. Skla likert digunakan untuk mengumpulkan pendapat guru dan siswa tentang penerapan model discovery secara daring pada pembelajaran menulis naskah ceramah. Pengukuran dalam skor dihitung dengan menggunakan kategori empat poin (SS) sangat setuju, tiga poin (S) setuju, (T) dua poin tidak setuju, dan satu poin (STS) sangat tidak setuju.Teknik pengumpulan data dilakukan dengan pengisian kuesioner melalui Google Form dan juga dilakukan wawancara terhadap guru dan siswa. Data yang terkumpul juga dianalisis dengan menggunakan reduksi data, verifikasi data, dan tiangulasi data untuk mendukung hasil dari temuan. Pengukuran skor data dari hasil angket dihitung dengan pengukuran skala likert. Pengukuran dalam skor dihitung dengan menggunakan kategori (SS) sangat setuju, (S) setuju, (T) tidak setuju, dan (STS) sangat tidak setuju (lihat Tabel 1).

Jumlah presentasi angket dinyatakan dalam bentuk kategori hasil penilaian. Kategori penilaian digunakan untuk mengetahui persepsi guru dan siswa terhadap penerapan model discovery secara daring pada pembelajaran menulis naskah ceramah (lihat Tabel 2).

Tabel 1. Bobot Penilaian Skala Likert

\begin{tabular}{lcc}
\hline Pilihan jawaban & Kode & Skor \\
\hline Sangat setuju & SS & 4 \\
Setuju & S & 3 \\
Tidak setuju & T & 2 \\
Sangat tidak setuju & STS & 1 \\
\hline
\end{tabular}


Tabel. 2 Kategori Penilaian Angket

\begin{tabular}{ll}
\hline Interval presentase & Kategori \\
\hline $86 \%-100 \%$ & Sangat baik \\
$85 \%-70 \%$ & Baik \\
$69 \%-54 \%$ & Kurang baik \\
$53 \%-38 \%$ & Tidak baik \\
\hline
\end{tabular}

\section{PEMBAHASAN}

Berdasarkan tabel 3 diketahui hasil dari persepsi guru terhadap penerapan model discovery secara daring pada pembelajaran menulis naskah ceramah yang terdiri dari indikator persepsi, kendala, dan evaluasi. Dari hasil tabel 3 menunjukkan bahwa nilai rata-rata persepsi $76.04 \%$ sementara nilai rata-rata kendala $69.79 \%$ dan nilai rata-rata evaluasi $77.08 \%$. Dari keseluruhan indikator nilai rata-rata diperoleh $73,75 \%$ dengan kategori baik. Berdasarkan perolehan data hasil kuesioner persepsi guru terhadap penerapan model discovery secara daring, maka data yang diperoleh dapat dilihat pada Tabel 3.

Selanjutnya, berdasarkan Tabel 4, diketahui hasil dari persepsi siswa terhadap penerapan model discovery secara daring pada pembelajaran menulis naskah ceramah yang terdiri dari indikator persepsi dan kendala. Dari hasil Tabel 4 menunjukkan bahwa nilai rata-rata persepsi $65 \mathrm{~m} 20 \%$ sementara nilai rata-rata kendala $60,07 \%$. Dari keseluruhan indikator nilai rata-rata diperoleh 63,06\% dengan kategori kurang baik.

Dari keseluruhan indikator nilai rata-rata persepsi guru diperoleh 73,75\% dengan kategori baik, sementara hasil keseluruhan dari persepsi siswa diperoleh nilai rata-rata 63,06\% dengan kategori kurang baik. Adapun diagram berdasarkan indikator persepsi dapat dilihat pada Gambar 1.

Tabel 3. Hasil Persepsi Guru

\begin{tabular}{lll}
\hline Indikator & Rata-rata & Kategori \\
\hline Persepsi & 76,04 & Baik \\
Kendala & 69,79 & Kurang Baik \\
Evaluasi & 77,08 & Baik \\
\hline Rata-rata & $\mathbf{7 3 , 7 5}$ & Baik \\
\hline
\end{tabular}

Tabel 4. Hasil Persepsi Siswa

\begin{tabular}{lll}
\hline Indikator & Rata-rata & Kategori \\
\hline Persepsi & 65,20 & Kurang Baik \\
Kendala & 60,07 & Kurang Baik \\
\hline Rata-rata & 63,06 & Kurang Baik \\
\hline
\end{tabular}




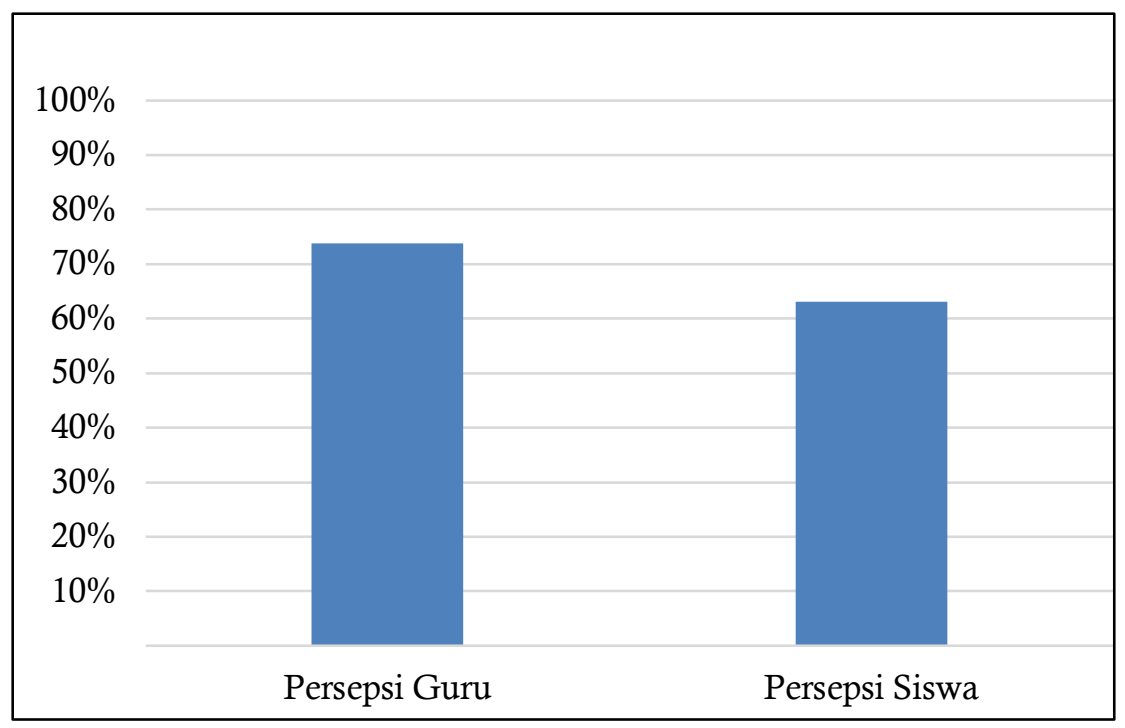

\section{Gambar 1. Persepsi Guru dan Siswa}

Dari penelitian ini, terdapat sebagian dari siswa mengatakan bahwa penerapan model discovery pada pembelajaran menulis naskah ceramah menjadikan siswa tidak aktif, sementara sebagian dari siswa juga berpendapat dalam penerapan model discovery secara daring pada pembelajaran menulis naskah ceramah menjadikan mereka aktif. Pembelajaran secara online juga tidak seefektif pembelajaran tatap muka. Beberapa siswa lain menganggap pembelajaran yang bermuara pada online tidak relevan dan merupakan hambatan dalam belajar (Ellis \& Bliuc, 2019). Respon pelajar dari hasil penelitian lain mengungkapkan bahwa ada beberapa pembelajaran yang tidak dapat diajarkan secara virtual yang dilaksanakan melalui online (Vivolo, 2016). Selain dari itu, persiapan untuk melaksanakan pembelajaran dalam kelas online memerlukan waktu cukup lama daripada kelas tatap muka (Boisselle, 2014). Hal ini dikarenakan adanya keterbatasan kuota dari siswa sendiri, dan model pembelajaran yang digunakan guru semasa daring tidak dapat diterapkan dengan baik. Selain itu, pembelajaran secara daring banyak memberikan beban kepada siswa dalam pemberian tugas dari guru maupun pengiriman tugas yang harus dikirim melalui online. Hal ini dapat menjadikan siswa bosan dan tidak aktif untuk mengikuti pembelajaran.

\section{PENUTUP}

Belajar dengan penerapan model discovery sangat menarik untuk diterapkan. Penerapan model discovery juga dapat menumbuhkan minat belajar dan motivasi siswa dalam mengikuti pembelajaran. Namun saat ini, belajar dengan menerapkan model discovery secara daring tidak seefisien pembelajaran tatap muka. Mengingat bahwa saat ini proses pembelajaran yang dilaksanakan secara daring tentu memerlukan kerja keras dari guru dalam hal menemukan strategi pengajaran yang menarik yang dapat menjadikan sisiwa aktif dalam mengikuti pemebelajaran. Keberhasilan siswa dalam proses pembelajaran menulis naskah ceramah secara daring bergantung pada guru dalam menentukan model pembelajaran. Beberapa masalah yang dihadapi guru maupun siswa saat pembelajaran onlie diantaranya jaringan internet yang terkadang terputus akibat padamnya lampu. Selain itu, siswa 
yang berada di pedesaan juga sulit menjangkau jaringan internet serta waktu yang digunakan dalam belajar secara daring terbatas.

Pada umumnya pembelajaran secara daring dengan penerapan model discovery di masa pandemi Covid-19 masih sulit di diterapkan terutama bagi siswa kurang memahami teknologi dan adanya keterbatasan dari segi materi. Hal ini diperlukan evaluasi mengenai kesiapan dalam proses pembelajaran secara daring dengan penerapan model discovery. Untuk itu, guru perlu memberikan motivasi kepada siswa agar lebih giat mengikuti proses pembelajaran secara daring. Namun dalam hal ini, pembelajaran dengan menerapkan model discovery secara daring masih dapat dimaksimalkan sehingga memungkinkan hasil belajar siswa lebih baik. Bagi peneliti selanjutnya yang sejalan dengan penelitian ini untuk dapat melakukan penelitian dengan menggunakan rumusan masalah yang lebih mendalam terkait dengan penerapan model discovery dalam pembelajaran secara secara daring.

\section{DAFTAR PUSTAKA}

Abdallah, M. M. S., \& Mansour, M. M. (2015). Virtual Task-Based Situated Language-Learning with Second Life: Developing EFL Pragmatic Writing and Technological Self-Efficacy. Arab World English Journal (AWEJ), Special Issue on CALL(2), 150-182. https://dx.doi.org/10.2139/ssrn.2843987

Adeninawaty, D., Soe'oed, R., \& Ridhani, A. (2018). Penerapan Model Pembelajaran Discovery Learning Strategi Think Talk Write dalam Meningkatkan Motivasi dan Hasil Belajar Menulis Teks Ulasan Kelas VIII SMP. Diglosia: Jurnal Kajian Bahasa, Sastra, dan Pengajarannya, 1(2), 75-88. https://doi.org/10.30872/diglosia.v1i2.11

Balım, A., G. (2009). The Effects of Discovery Learning on Students' Success and Inquiry Learning Skills. Egitim Arastirmalari-Eurasian Journal of Educational Research, 35, 1-20. https://ejer.com.tr/wpcontent/uploads/2021/01/ejer_2009_issue_35.pdf

Boisselle, L. N. (2014). Online-Learning and Its Utility to Higher Education in the Anglophone Caribbean, 4(4). https://doi.org/10.1177/2158244014555118

Afandi, M., Chamalah, E., \& Wardani, O. P. (2013). Model dan Metode Pembelajaran di Sekolah. Semarang: Unissula Press.

Daniel, M. C., Schumacher, G., Stelter, N., \& Riley, C. (2016). Student Perception of Online Learning in ESL Bilingual Teacher Preparation. Universal Journal of Educational Research, 4(3), 561-569. https://doi.org/10.13189/ujer.2016.040313

Ellis, R. A., \& Bliuc, A. (2019). Exploring New Elements of the Student Approaches to Learning Framework : the Role of Online Learning Technologies in Student Learning. Active Learning in Higher Education, 20(1), 11-24. https://doi.org/10.1177/1469787417721384

Kellogg, R. T., \& Raulerson, B. A. (2007). Improving the writing skills of college students. Psychonomic Bulletin and Review, 14(2), 237-242. https://doi.org/10.3758/BF03194058

Magnani, L., Nersessian, N. J., \& Thagard, P. (eds.). (1999). Model-Based Reasoning in Scientific Discovery. Switzerland: Springer Nature. https://link.springer.com/book/10.1007/978-1-4615-4813-3

Martin, F., \& Bolliger, D. U. (2018). Engagement matters: Student perceptions on the importance of engagement strategies in the online learning environment. 
Online Learning Journal, 22(1), 205-222. https://doi.org/10.24059/olj.v22i1.1092

Rastle, K. (2019). EPS mid-career prize lecture 2017: Writing systems, reading, and language. Quarterly Journal of Experimental Psychology, 72(4), 677-692. https://doi.org/10.1177/1747021819829696

Rosalina, G., Sudin, A., \& Sujana, A. (2012). Penerapan Model Discovery Learning untuk Meningkatkan Hasil Belajar Siswa pada Materi Perubahan Wujud Benda. Jurnal Pena Ilmiah, 1(1), 371-380. https://ejournal.upi.edu/index.php/penailmiah/article/view/3043

Sabaruddin. (2019). Facebook Utilisation to Enhance English Writing Skill. English Language Teaching, 12(8), 37-43. https://doi.org/10.5539/elt.v12n8p37

Saputro, A. M., Arifin, M. B., \& Hefni, A. (2021). Pengembangan Bahan Ajar Menulis Cerita Pendek dengan Pendekatan Kontekstual Berbasis Kearifan Lokal pada Siswa Kelas XI SMK. Diglosia: Jurnal Kajian Bahasa, Sastra, dan Pengajarannya, 4(2), 235-246. https://doi.org/10.30872/diglosia.v4i2.98

Sherbino, J., Chan, T., \& Schiff, K. (2013). The Reverse Classroom: Lectures on Your Own and Homework with Faculty. Canadian Journal of Emergency Medicine, 15(3), 178-180. https://doi.org/10.2310/8000.2013.130996

Simbolon, M. (2008). Persepsi dan Kepribadian. Jurnal Ekonomi dan Bisnis, 2(1), 5266. https://jurnal.unai.edu/index.php/jeko/article/view/516

Skeen, T., \& Zafonte, M. (2015). Teaching APA Style Documentation: Discovery Learning, Scaffolding and Procedural Knowledge. Journal of Instructional Research, 4, 69-75. https://doi.org/10.9743/jir.2015.9

Tanggaard, L. (2014). A Situated Model of Creative Learning. European Educational Research Journal, 13(1), 107-116. https://doi.org/10.2304/eerj.2014.13.1.107

Traweek, A. C. (2017). Integrating Writing in the Classics Classroom. Journal of Classics Teaching, 18(35), 26-30. https://doi.org/10.1017/s2058631017000034

Turan, S., \& Matteson, S. M. (2021). Middle School Mathematics Classrooms Practice Based on 5E Instructional Model. International Journal of Education in Mathematics, Science and Technology, 9(1), 22-39. https://doi.org/10.46328/ijemst.1041

Vivolo, J. (2016). Understanding and Combating Resistance to Online Learning, 99, 399412. https://doi.org/10.3184/003685016X14773090197742 
